\title{
Albendazole increases serum retinol concentration in primary schoolchildren with low serum retinol
}

\author{
Jane Florida Kalumpiu, **** Yenny Djuardi,*** Taniawati Supali, **** \\ and Ria Buana******
}

\begin{abstract}
*Biomedical Sciences Master

Program,

Faculty of Medicine,

University of Indonesia

** Department of Parasitology,

Faculty of Medicine,

Trisakti University

BACKGROUND

Soil-transmitted helminth (STH) infection is still a health problem in Indonesia. Vitamin A deficiency (VAD) is often found together with STH. The effect of the deworming program on the vitamin A status of primary school children is unknown. The objective of this study was to evaluate the effect of albendazole on serum retinol concentrations in primary school children.
\end{abstract}

***Department of Parasitology,

Faculty of Medicine,

University of Indonesia

****Department of Parasitology,

Faculty of Medicine,

Tarumanagara University

\section{Correspondence:}

dr. Jane Florida Kalumpiu,

M.Biomed

Faculty of Medicine,

Trisakti University

Jl. Kyai Tapa No. 260 Grogol,

Jakarta 11440

Phone:+6221-5672731 ext.2311

Email: jane.mikejane@gmail.com

Univ Med 2015;34:121-8

DOI: 10.18051/UnivMed.2016.v35.121-128 pISSN: 1907-3062 / eISSN: 2407-2230

This open access article is distributed under a Creative Commons Attribution-Non Commercial-Share Alike 4.0 International License

\section{METHODS}

An experimental study of pre-post test design without control was carried out on 118 children from grades 3-5 at one primary school in North Jakarta, from July to September 2014. Flotac examination was used to determine STH infections and high performance liquid chromatography was performed to measure serum retinol concentration. Stool and blood samples were taken twice: before and three weeks after treatment with albendazole $400 \mathrm{mg}$ single dose for three consecutive days given to all children either infected or uninfected. Paired t-test was used to analyze the data.

\section{RESULTS}

Of the 118 children, the prevalence of STH was $71.2 \%$. The prevalence of low retinol serum $(<1.05 \mu \mathrm{mol} / \mathrm{L})$ was $17(17.2 \%)$ and of mild VAD was $2(2.0 \%)$. Albendazole given in 3 consecutive days could not increase serum retinol concentrations $(\mathrm{p}=0.055)$. Serum retinol concentration significantly increased after albendazole treatment in children with low retinol serum at baseline $(\mathrm{p}=0.001)$.

\section{CONCLUSIONS}

In children with low serum retinol concentration, treatment with albendazole increased retinol concentration. Integrated deworming and vitamin A supplementation strategies should be evaluated in this population.

Keywords: Albendazole, retinol, vitamin A status, primary schoolchildren 


\section{Pemberian albendazol meningkatkan kadar retinol dalam serum pada murid sekolah dasar dengan kadar retinol rendah}

\section{ABSTRAK}

\section{LATAR BELAKANG}

Infeksi soil-transmitted helminthes (STH) masih merupakan masalah kesehatan di Indonesia. Prevalensi kurang vitamin A (KVA) sering ditemukan bersamaan dengan STH. Penelitian ini bertujuan untuk menilai pengaruh pemberian albendazol terhadap konsentrasi retinol dalam serum pada anak usia sekolah.

\section{METODE}

Penelitian eksperimental pra-pasca perlakuan tanpa kontrol dilakukan pada murid sekolah dasar kelas 3-5 di salah satu SDN di Jakarta Utara. Sebanyak 118 subjek ikut serta pada penelitian, tetapi hanya 88 subjek yang dapat diikuti sampai selesai studi. Pemeriksaan Flotac dilakukan untuk menentukan infeksi dan intensitas STH. Konsentrasi retinol dalam serum diukur menggunakan pemeriksaan Kromatografi Cair Kinerja Tinggi. Sampel tinja dan darah diambil dua kali yaitu sebelum dan tiga minggu sesudah pengobatan dengan albendazol $400 \mathrm{mg}$ dosis tunggal selama tiga hari berturut-turut yang diberikan pada semua anak. Uji t-pasangan digunakan untuk analisis data.

\section{HASIL}

Dari 118 subjek didapatkan prevalence STH sebesar 71,2\%. Prevalence subjek dengan kadar retinol yang rendah $(<1,05 \mu \mathrm{mol} / \mathrm{L})$ ditemukan sebesar 17 (17,2\%) anak, dan KVA ringan $(<0,70 \mu \mathrm{mol} / \mathrm{L})$ sebanyak 2 (2,0\%). Pemberian albendazol selama 3 hari berturut-turut tidak meningkatkan kadar retinol dalam serum $(p=0,055)$. Ternyata pada subjek yang kadar retinolnya rendah, pemberian albendazol mampu meningkatkan secara bermakna konsentrasi retinol dalam serum $(p=0,001)$.

\section{KESIMPULAN}

Pada subjek dengan kadar retinol yang rendah, pemberian albendazole mampu meningkatkan kadar retinol serum. Pengobatan abendazol untuk STH harus dilakukan bersamaan dengan vitamin A untuk mengatasi KVA pada murid Sekolah Dasar.

Kata kunci: Albendazol, retinol, status vitamin A, murid sekolah dasar

\section{INTRODUCTION}

Helminthiasis is still one of the health problems in the world, particularly in developing tropical and subtropical countries, including Indonesia. ${ }^{(1)}$ It has been estimated that around two thousand million people are infected with at least one of these parasites, with the highest prevalence found in poor areas with poor sanitation and hygiene..$^{(1,2)}$

In Indonesia helminthiasis is widespread in both rural and urban areas. A study covering several Asian and African countries showed in 2010 that the prevalence of soil-transmitted helminths (STHs) in Indonesia was $24.6 \%$. $^{(3)}$

Young children are also disadvantaged by one or more of the soil-transmitted helminths (STHs): Ascaris lumbricoides (roundworm), Trichuris trichiura (whipworm), and Ancylostoma duodenale/Necator americanus (hookworms). ${ }^{(4)}$ Although not fatal, helminthiasis has a wide impact, resulting among other things in malnutrition, anemia, abnormal cognitive functions, and decreased school performance so 
that it may decrease the quality of Indonesian human resources. ${ }^{(1)}$ The strategy recommended by the WHO to reduce the morbidity resulting from STHs is the administration of anthelmintics of the benzimidazole group, i.e. albendazole $400 \mathrm{mg}$ or mebendazole $500 \mathrm{mg}$ single dose. These drugs should be given periodically once or twice a year, depending on the baseline STH prevalence found in primary school children. ${ }^{(1)}$

The World Health Organization (WHO) has recommended that the delivery of vitamin $\mathrm{A}$ capsules and anthelmintic tablets should be simultaneous as worm infections and vitamin $\mathrm{A}$ deficiency (VAD) have the same geographical distribution. ${ }^{(5)}$ Vitamin A, a fat soluble vitamin found in different forms such as retinol and provitamin A carotenoids, is essential for cell proliferation, immune functions, vision, gene expression, and excretion of growth hormone. ${ }^{(6)}$ Moreover, vitamin A derivatives play a major role in the development of the central nervous system. In addition, it helps maintain the integrity of the skin and mucous membranes that act as a barrier to pathogens. (7) Previous in vivo studies have shown beneficial effects of vitamin A supplementation on tissue inflammation and innate and adaptive immunity in humans by downregulating inflammatory responses, enhancing immunoglobulin production, promoting the differentiation of $\mathrm{T}$ and $\mathrm{B}$ cells and modulating cytokine production. ${ }^{(7)}$ An estimated 4.5 billion people of the world are at risk of intestinal parasites, and 1.2 billion might be infected with roundworms, such as Ascaris lumbricoides. ${ }^{(8,9)}$ Vitamin A supplementation showed no effect on reinfection with A. lumbricoides (OR: 1.11, 95\% CI: 0.79-1.56). ${ }^{(10)}$ With regards to a reduction of A. lumbricoides infection intensity, only one lowquality evidence with moderate-to-weak positive effects was found. ${ }^{(11)}$ Vitamin A increased the odds of having improved levels of IL-4, which is part of the Th2 response against helminths, in one study (strong positive effect, high quality evidence). ${ }^{(10)}$

A study in Bangladesh on children aged 2460 months showed that administration of albendazole only at a dose of $400 \mathrm{~g} /$ day at baseline and 4 months later, was able to increase serum retinol concentrations. ${ }^{(12)}$ Studies of preschool-age children in Bangladesh, India, and Indonesia, however, showed that combined deworming and supplementation with beta-carotene, an inactive form of vitamin A, resulted in the greatest rise in serum retinol levels, as compared to children treated with deworming alone or beta-carotene supplementation exclusively. ${ }^{(12,13)}$ While there is some evidence to suggest an added benefit to combined deworming and vitamin A supplementation, a number of studies in similar settings have either been unable to reproduce this positive outcome or have not specifically tested the combined intervention. ${ }^{(14)}$ Thus, while the WHO and the United Nations Children's Fund (UNICEF) recommend that benzimidazole anthelminthics can be safely coadministered with vitamin $A$, the potential synergies of deworming with vitamin A supplementation are neither well documented nor consistent. There is a need for additional studies, especially randomized clinical trials, given the frequent coexistence of dietary deficiency and infection in endemic areas. ${ }^{(15)}$ The aim of the present study was to evaluate the effect of albendazole administration on serum retinol concentration in primary school children.

\section{METHODS}

\section{Design of the study}

An experimental study of pre-post test design without control was carried out from July to December 2014 in a state primary school in North Jakarta.

\section{Study subjects}

Primary school children aged 9-11 years were recruited for this study. The inclusion criteria for the study subjects were: (a) apparently healthy without a history of chronic illness, and (b) willing to take daily one dose of albendazole during the study. In calculation of the sample size, the level of significance $(\alpha)$ was 0.05 two-sided, and the power $(\beta)$ was 0.90 . The selection of mean differences was taken $25 \%$ after albendazole 
supplementation. Taking into account a $20 \%$ dropout rate and the design effect, the sample size was increased to 71 children. The children participated in this study with the informed consent of their parents.

\section{Intervention}

Each of the children participating in this study were given a single oral dose of albendazole chewable tablets of $400 \mathrm{mg}$ (IndoFarma) for three consecutive days. The anthelminthic tablets were chewed directly in front of the investigators.

\section{Stool sample collection}

Stool samples were collected in stool pots given on the previous day to the children through their respective home room teachers. The subjects had been given explanations on the stool collection method. For stool sample collection the children were given three days, after which the stool samples were collected directly by the team of investigators and transported to the laboratory. The stool sample collection was performed twice during the study, i.e. at baseline and three weeks after the last treatment.

\section{Stool examination by the FLOTAC technique}

One gram of stool sample was weighed, 10 $\mathrm{ml}$ of $5 \%$ formaline solution was added, and stored at room temperature waiting for the examination. All collected stool samples were examined by the FLOTAC technique at the Parasitology Laboratory, Faculty of Medicine, University of Indonesia. To one gram of stool sample was added $11 \mathrm{ml}$ distilled water and the mixture homogenized and centrifuged at $1500 \mathrm{rpm}$ for three minutes, and the supernatant discarded. A volume of $11 \mathrm{ml}$ Flotac solution (sucrose) was added and the mixture homogenized. Five $\mathrm{ml}$ of the homogenate was placed into the Flotac instrument, centrifuged at $1000 \mathrm{rpm}$ for 5 minutes. The positive results of microscopic examination was presented as epg (eggs per gram).

\section{Serum â-carotene determination}

Blood samples were drawn from the antecubital vein by an experienced phlebotomist to the amount of 2-3 $\mathrm{ml}$ directly into a vacutainer tube containing a clot activator and separator gel and stored in a cool box containing icepacks and protected from light. The blood samples were then transported to the laboratory to be centrifuged and the serum was placed in a serum cup and stored in a freezer at minus $20^{\circ} \mathrm{C}$ for further examination. Blood samples were drawn twice, at baseline and three weeks after administration of the anthelminthic. Determination of serum retinol concentration was performed at the SEAMEO Laboratory, Faculty of Medicine, University of Indonesia, by high performance liquid chromatography (HPLC). To $40 \mu \mathrm{l}$ of the serum sample to be assessed was added $100 \mu \mathrm{l}$ of extraction solution (acetonitryl-methanol 1:1), manually shaken for one minute, and subsequently centrifuged at $12.000 \mathrm{rpm}$ and $4{ }^{\circ} \mathrm{C}$ for three minutes. Approximately $20 \mu \mathrm{L}$ of the supernatant was injected into the HPLC apparatus (flow rate $1 \mathrm{~mL} /$ minute, column Novapack C18 (3.9 x 150 $\mathrm{mm}$ ), wavelength $325 \mathrm{~nm}$ ). Then pooled serum of known value was injected as control for every 10 or 20 samples. Serum retinol concentration was presented in $\mu \mathrm{mol} / \mathrm{L}$. Normal serum retinol concentration is $\geq 1.05 \mu \mathrm{mol} / \mathrm{L}$. ${ }^{(16)}$

\section{Data analysis}

To compare the baseline and follow-up values within the treatment groups, a paired $t-$ test was used. Significance was defined as $p<0.05$.

\section{Ethical clearance}

All procedures to be performed in this study had been explained to the respective teachers, parents, and children, and had obtained ethical clearance from the Health Research Ethics Committee, Faculty of Medicine, University of Indonesia.

\section{RESULTS}

Of the 118 children recruited, complete data were available from 88 (88.9\%) after three months. Thirty children did not complete the trial for various reasons, including sickness, and refusal to take supplements (Figure 1). 


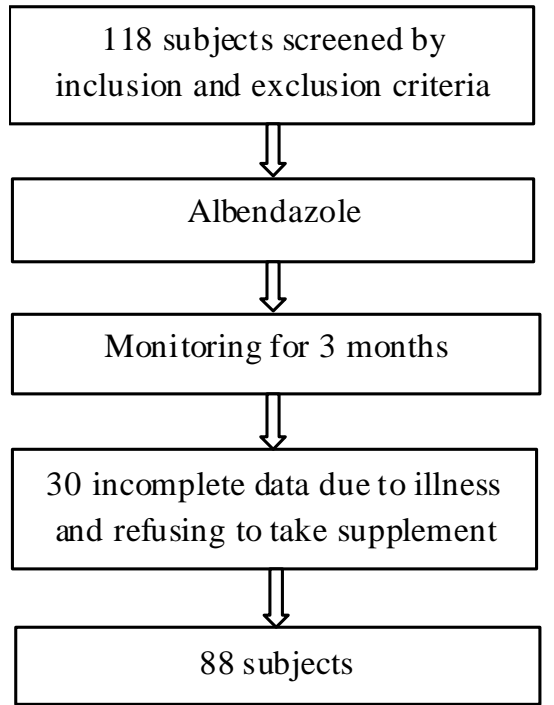

Figure 1. Flow of subject participation during study

There were about equal numbers of males and females (49.2\% and 50.8\%), and the percentage of children with STH infection was $71.2 \%$. Demographically, the school children of State Primary School 07 (SDN 07) resided not far from school. The majority of the children's

Table 1. Distribution of sociodemographic characteristics, infection status, and retinol concentrations at baseline $(\mathrm{n}=118)$

\begin{tabular}{|c|c|}
\hline Variab le & n (\%) \\
\hline \multicolumn{2}{|c|}{ Sociodem og aphic charad eristics } \\
\hline \multicolumn{2}{|c|}{ Age (years) } \\
\hline 9 & $30(25.5)$ \\
\hline 10 & $62(52.5)$ \\
\hline 11 & $26(22.0)$ \\
\hline \multicolumn{2}{|l|}{$\mathrm{G}$ ender } \\
\hline Male & $58(49.2)$ \\
\hline Fem ale & $60(50.8)$ \\
\hline \multicolumn{2}{|l|}{ P arents' education } \\
\hline Primary school & $29(24.6)$ \\
\hline Junior high school & $49(41.5)$ \\
\hline Seri or high school & $40(33.9)$ \\
\hline \multicolumn{2}{|l|}{ P arents' occupation } \\
\hline Non-workers & $28(23.7)$ \\
\hline Workers & $90(76.3)$ \\
\hline \multicolumn{2}{|l|}{ Infection status } \\
\hline Infect ed & $84(71.2)$ \\
\hline $\mathrm{N} d$ infeded & $34(28.8)$ \\
\hline \multicolumn{2}{|c|}{ Retinol concentration ( $\mu \mathrm{m}$ ol/L) } \\
\hline$<1.05 \mu \mathrm{m} \mathrm{d} / \mathrm{L}$ & $17(17.2)$ \\
\hline$\geq 1.05 \mu \mathrm{m} \mathrm{d} / \mathrm{L}$ & $82(82.8)$ \\
\hline
\end{tabular}

parents were laborers (76.3\%) while the remainder were business people, employees, fishers, and drivers. The highest educational level of the parents varied from primary school to senior high school, the majority $(41.5 \%)$ being junior high school graduates (Table 1).

The blood samples collected at baseline (before treatment) was 99 and after treatment 88. At baseline mean serum retinol concentration was $1.38 \pm 0.35 \mu \mathrm{mol} / \mathrm{L}$. At baseline there were $17(17.2 \%)$ children with serum retinol concentrations of $<1.05 \mu \mathrm{mol} / \mathrm{L}$ (mild vitamin A deficiency) and there were $2(2.0 \%)$ children with serum retinol concentrations of $<0.70 \mu \mathrm{mol} /$ $\mathrm{L}$ (severe vitamin A deficiency). After treatment mean serum retinol concentration was $1.45 \pm$ $0.39 \mu \mathrm{mol} / \mathrm{L}$, which was not significantly different from mean serum retinol concentration at baseline $(\mathrm{p}=0.055)$ (Table 2). It was found that in subjects with baseline serum retinol concentrations below normal $(<1.05 \mu \mathrm{mol} / \mathrm{L})$, albendazole administration was able to significantly increase serum retinol concentrations $(\mathrm{p}=0.001)$ (Table 2). Based on infection status at baseline, mean serum retinol concentration before and after albendazole administration were not significantly different. This was shown by subjects with and without STH infection (Table 2).

\section{DISCUSSION}

Our study results showed that subjects with STH infection accounted for $71.2 \%$, which is similar to the results of a study in Pahang, Malaysia, in which subjects who were infected with at least one STH species comprised 98.6\%. ${ }^{(6)}$ Soil-transmitted helminthiases caused by Ascaris lumbricoides, Trichuris trichiura and hookworm are among the most common neglected tropical diseases (NTDs) by infecting about 1,200 million people worldwide with the greatest morbidity being among children and mothers of childbearing age. ${ }^{(17,18)}$ The main impact of STH infections is their association with malnutrition, vitamin A deficiency (VAD) and iron deficiency anaemia (IDA), which may 
Table 2. Retinol concentration before $(n=118)$ and after intervention $(n=88)$

\begin{tabular}{lccc}
\hline & \multicolumn{2}{c}{ Intervention } & \multirow{2}{*}{ p } \\
\cline { 2 - 3 } & Before (n=118) & After $(\mathbf{n}=\mathbf{8 8})$ & \\
\hline Retinal concentration $(\mu \mathrm{mol} / \mathrm{L})$ & $1.38 \pm 0.35$ & $1.45 \pm 0.39$ & 0.055 \\
Not infected & $1.34 \pm 0.39$ & $1.42 \pm 0.37$ & 0.145 \\
Infected & $1.40 \pm 0.33$ & $1.47 \pm 0.41$ & 0.191 \\
Normal baseline retinol concentration $(\geq 1.05 \mu \mathrm{mol} / \mathrm{L})$ & $1.48 \pm 0.38$ & $1.51 \pm 0.39$ & 0.593 \\
Low baseline retinol concentration $(<1.05 \mu \mathrm{mol} / \mathrm{L})$ & $0.87 \pm 0.39$ & $1.18 \pm 0.29$ & $0.001^{*}$ \\
\hline
\end{tabular}

have effects at the community level with regard to work and productivity in adults and growth, learning and school performance in children. ${ }^{(19)}$

In our study the prevalence of subjects with mild vitamin A deficiency (having a serum retinol concentration of $<1.05 \mu \mathrm{mol} / \mathrm{L}$ ) was $17.2 \%$ and the prevalence of subjects with severe vitamin A deficiency (with a serum retinol concentration of $<0.70 \mu \mathrm{mol} / \mathrm{L}$ ) was $2 \%$. The prevalence in the population with low serum retinol $(0.70$ $\mu \mathrm{mol} / \mathrm{l}$ or below) can be used to assess the severity of vitamin A deficiency in most age groups as a public health problem. There is said to exist a mild public health problem if the prevalence of subjects with low serium retinol $(0.70 \mu \mathrm{mol} / \mathrm{L}$ or below $)$ is $2.0-9.0 \%$, moderate if $10.0-19.0 \%$ and severe if $20.0 \%$ or more. ${ }^{(16)}$ The population in our study had a mild public health problem with regard to vitamin A deficiency.

Our study showed an increase in serum retinol concentration after administration of albendazole, although the increase was not significant from that before administration of albendazole. Similar results were shown in a study on preschool children in Bangladesh, in which oral albendazole administration at a dose of $400 \mathrm{mg}$ did not significantly increase serum retinol concentration. ${ }^{(20)}$ In communities in which vitamin A deficiency coexists with soil helminth infection, deworming alone and in combination with vitamin A supplementation has been explored as a means to correct or reduce deficiency in infected children. A population study in Uttar Pradesh, India, found that twice-yearly deworming alone of lightly infected children did not result in either significant weight gain or a reduction in mortality. ${ }^{(21)}$ Studies of preschool-age children in Bangladesh, India, and Indonesia, however, showed that combined deworming and supplementation with betacarotene, an inactive form of vitamin A, resulted in the greatest rise in serum retinol levels, as compared to children treated with deworming alone or beta-carotene supplementation exclusively. ${ }^{(4,20)}$ While there is some evidence to suggest an added benefit to combined deworming and vitamin A supplementation, a number of studies in similar settings have either been unable to reproduce this positive outcome or have not specifically tested the combined intervention. ${ }^{(14)}$ Thus, while the WHO and the United Nations Children's Fund (UNICEF) recommend that benzimidazole anthelminthics can be safely coadministered with vitamin A the potential synergies of deworming with vitamin A supplementation are neither well documented nor consistent. ${ }^{(22)}$ There is a need for additional studies, especially randomized clinical trials, given the frequent coexistence of dietary deficiency and infection in endemic areas.

One of the limitations of our study was the lack of controls, so that the obtained results could not be compared with that of controls. The proportion of subjects that was successfully followed up to the completion of the study was still below $90.0 \%$, which may have influenced the obtained study results. There is a need for additional studies, especially randomized clinical trials, given the frequent coexistence of dietary deficiency and infection in endemic areas. 


\section{CONCLUSIONS}

The STH prevalence in primary school children is still relatively high. Albendazole administration is capable of increasing serum retinol concentrations in subjects with low serum retinol concentrations. Multi-pronged approaches are probably necessary to prevent and control the negative effects of STH infections, including anthelminthic drugs, and, possibly improved nutrition.

\section{CONFICT OF INTEREST}

The authors declare that they have no competing interests.

\section{ACKNOWLEDGEMENT}

The investigators thank Prof Dra Taniawati Supali and dr. Yenny Djuardi, Phd. for guidance and consultations during the study. Thanks are also due to Prof Dr dr Adi Hidayat, MS for his willingness to edit this article.

\section{DAFTAR PUSTAKA}

1. World Health Organization. Eliminating STH as a public health problem in children. Geneva: World Health Organization;2012.

2. Knoop S, Steinman P, Keiser J, et al. Nematode infections soil-transmitted helminths and Trichinella: Infect Dis Clin N Am 2012;26:34158.

3. Pullan RL, Smith JL, Jasrasaria R, et al. Global numbers of infection and disease burden of soil transmitted helminth infections in 2010. Parasites Vectors 2014;7:37. doi: 10.1186/17563305-7-37.

4. Albonico M, Allen H, Chitsulo L, et al. Controlling soil-transmitted helminthiasis in pre-school age children through preventive chemotherapy. PLoS Negl Trop Dis 2008;2: e126. doi: 10.1371/journal.pntd.0000126.

5. World Health Organization. Preventive chemotherapy in human helminthiasis. World Health Organization. 2006.

6. Al-Mekhlafi HM, Anuar TS, Al-Zabedi EM, et al. Does vitamin A supplementation protect schoolchildren from acquiring soil-transmitted helminthiasis? A randomized controlled trial. Parasites Vectors 2014;7:367. doi: 10.1186/17563305-7-367.

7. Hurst RJ, Else K. Retinoic acid signalling in gastrointestinal parasite infections: lessons from mouse models. Parasite Immunol 2012;34:3519.

8. Bethony J, Brooker S, Albonico M, et al. Soiltransmitted helminth infections: ascariasis, trichuriasis, and hookworm. Lancet 2006;367: 1521-32.

9. Brooker S, Clements AC, Bundy DA. Global epidemiology, ecology and control of soiltransmitted helminth infections. Adv Parasitol 2006;62:221-61.

10. Long KZ, Rosado JL, Montoya Y, et al. Effect of vitamin $\mathrm{A}$ and zinc supplementation on gastrointestinal parasitic infections among Mexican children. Pediatrics 2007;120:e846e855.

11. Payne LG, Koski KG, Ortega-Barria E, et al. Benefit of vitamin A supplementation on Ascaris reinfection is less evident in stunted children. $\mathrm{J}$ Nutr 2007;137:1455-9

12. Haque R, Ahmed T, Wahed MA, et al. Low-dose $B$-carotene supplementation and deworming improve serum vitamin $A$ and $B$-carotene concentration in preschool children of Bangladesh. J Health Popul Nutr 2010;28:23037.

13. Albonico M, Allen H, Chitsulo L, et al. Controlling Soil-Transmitted Helminthiasis in Pre-School-Age Children through Preventive Chemotherapy. PLoS Negl Trop Dis 2008;2: e126. doi: 10.1371/journal.pntd.0000126.

14. Tanumihardjo SA, Permaesih D, Muhilal. Vitamin A status and hemoglobin concentrations are improved in Indonesian children with vitamin $\mathrm{A}$ and deworming interventions. Eur $\mathrm{J}$ Clin Nutr 2004;58:1223-30. doi: 10.1038/sj.ejen. 1601953.

15. Rajagopal S, Hotez PJ, Bundy DAP. Micronutrient supplementation and deworming in children with geohelminth infections. PLOS Negl Trop Dis 2014;8:e2920. doi:10.1371/ journal.pntd.0002920.

16. World Health Organization. Serum retinol concentrations for determining the prevalence of vitamin A deficiency in populations. Geneva: World Health Organization; 2011.

17. Surin J. The burden of moderate-to-heavy soiltransmitted helminth infections among rural Malaysian aborigines: an urgent need for an integrated control programme. Parasites Vectors 2011;4:242. 
18. World Health Organization. Soil-transmitted helminthiases. Eliminating soil-transmitted helminthiases as a public health problem in children: Progress Report 2001-2010 and Strategic Plan 2011-2020. Geneva: World Health Organisation; 2012.

19. Yap P, Utzinger J, Hattendorf J, et al. Influence of nutrition on infection and re-infection with soil-transmitted helminths: a systematic review. Parasites Vectors 2014;7:229. doi:10.1186/17563305-7-229.
20. Haque R, Ahmed T, Wahed MA, et al. Low-dose â-carotene supplementation and deworming improve serum vitamin $\mathrm{A}$ and â-carotene concentrations in preschool children of Bangladesh. J Health Popul Nutr 2010;28:2307.

21. Awasthi S, Peto R, Read S, et al. Population deworming every 6 months with albendazole in 1 million pre-school children in North India: DEVTA, a clusterrandomized trial. Lancet 2013; 381:1476-86.

22. World Health Organization. How to add deworming to vitamin A distribution. Geneva: World Health Organization;2004. 